\title{
ANALYZING LEARNING AUTONOMY IN READING ENGLISH TEXT AT MTS DDI AS-SALMAN SIDRAP
}

\author{
Nur Asiza, Abd. Haris Sunubi \\ IAIN PAREPARE \\ Bulqis_alfarabi@yahoo.co.id
}

\begin{abstract}
This research is aimed at investigating the implementation of autonomous learning. Autonomous learning consists of three aspects: self-planning, self-monitoring, and self-evaluating. This research is a use a mixed-method sequential explanatory design. The subject of the research is 24 students of the first grade students of junior high school. The writer observed the classroom, and also gave a set of questionnaire to the students to find out whether they are an autonomous learner or not. The result showed that in self-planning aspect, 56.83\% students are self-planned; they are categorized into "poor". In self-monitoring aspect, $81.85 \%$ students are self-monitored; they are categorized into "good". In self-evaluating aspect, $62.53 \%$ students are self-evaluated; they are categorized into "fair". So, the students got good category in self-monitoring aspect, whereas for self-planning and self-evaluating must be improved.
\end{abstract}

Keywords: autonomous learning, self-planning, self-monitoring, self-evaluating.

\section{INTRODUCTION}

There are some components which would be discussed in this fragment namely, background of the research, problem which was identified, and problem solution alternatives.

English occupies a unique position among the languages of the world. English is used more widely by more people around than any language as means of communication internationally in every field, politics, economics, and social life. So it would not be a surprising matter that English is learned in many parts of the world as reported in the United Nation statistically yearbook. Proficiency in English becomes not only a must but also an urgent need especially in Indonesia.

Students' language development depends on what they experience in teaching and learning process. Teachers of English should be able to create meaningful learning activities. How learners acquire a language, Mustafa suggests that the language learners need ample exposure, engagement, and supports. He, further, elaborates that the most 
serious challenges facing our English teachers include the issue of exposure to real-life English use, student engagement in real-life communicative activities, and all kinds of environmental supports, which according to research, contribute to the development of learners as communicatively competent users of English for communicative purposes.

Schools of thought in second language acquisition ranging from structuralism/behaviorism, rationalism and cognitive psychology until constructivism have been taken as approaches. Constructivism assumes that humans generate knowledge and meaning from interaction between estudents' experiences and their ideas. It emphasizes the importance of the learner being actively involved in the learning process.

Ministry of education and culture of Indonesia has already published the new curriculum for Indonesia's education, 2013 curriculum. The new 2013 curriculum requires students to be more active and independent. This curriculum also requires the teacher to become the facilitator not the provider in the class. To reduce the teacher-centered in a classroom, the students should be able to move away and become autonomous learners. Learnercentered rather than teacher-centered classrooms gives students the opportunity to become active participants in the learning process, making decisions with regard to the learning objectives and materials to be used, and helping to decide the evaluation process, thus moving toward becoming independent and autonomous learners. This is why the researchers is interested in investigating whether the autonomous learning has been implemented by the students, especially in Islamic junior high school because that school has already implemented 2013 curriculum.

\subsection{Problem Identification}

After interviewing English Teacher of MTs DDI As-Salman, the researchers noticed in reading comprehension an autonomous learner may face problems like time allocation for reading, unfamiliar words in the text, and also difficulties in finding main idea and supporting detail. The English teacher there said that actually, there are many difficulties that faced by students in studying reading. For instance, the students are shy, bored, lack of vocabulary, and do not have self-confidence, so that make the students cannot read English well. In the other case the students seem to rely on the teacher and they tend to become a passive learner. The students are expected to be more independent. Autonomous can be described as a capacity to take charge of, or take responsibility for, or control over your own learning.

\subsection{Problem Solution Alternative}

Therefore, the students need to be more autonomous in learning. Autonomy learning makes the students have their own way to study and this makes them more creative and enthusiastic about learning. Students can find out what they really need in the learning process and they can explore the material.

The teacher should help their students set their learning goals creating a friendly atmosphere in the classroom which leads to discussion, analysis and evaluation; encouraging 
them to work collaboratively in small groups; asking the learners to keep a record of their learning and evaluate their progress both as individual learners and as a class again in the target language are among the tasks. This means that in autonomous learning the teacher is the facilitator in learning process. Autonomy learning process makes the students more active in the learning process as expert noticed "increasing the level of learner control will increase the level of self-determination, thereby increasing overall motivation in the development of learner autonomy". Learner autonomy refers to encouraging students "to determine the objectives, to define the contents and progressions, to select methods and techniques to be used, to monitor the procedures of acquisition and to evaluate what has been acquired".

To help students overcome these problems, teachers can ask them to read and underline unknown words, looking up the meaning in dictionary and to use contextual clues to guess the general meaning. The students are expected to be more independent and can solve the problems in reading by themselves.

\section{LITERATURE REVIEW}

\subsection{Some Related Research Findings}

Some researcher had researched about this material namely:

Phil Benson on his research, "Autonomy In And Out OfClass “. He found that a focus on the characteristics of settings for learning beyond the classroom and variations within them.

Leni Dam on her research How Do We Recognize an Autonomous Classroom?-Revisited. She reported that the development of the learners' self-esteem and self-confidence. On the one hand, self-esteem is a prerequisite for developing autonomy, and on the other hand, autonomy enhances the learners' self-esteem.

Dam L stated that autonomous learning was effective in terms of vocabulary acquisition, which is one conventional indicator of successful language learning.

Based on the previous findings above, the researchers concluded that in teaching and learning English, learning autonomy can be applied to energize the students' self-confidence, self-esteem and improve their English.

\subsubsection{The Concept of Learning Autonomy}

There is broad agreement in the theoretical literature that learner autonomy grows out of the individual learner's acceptance of responsibility for his or her own learning. This means that autonomy requires the learner to develop control over his or her own learning and his or her own role in that process. According to Benson, this control might take various forms for different individuals and even different forms for the same individual depending on the contexts or times. For instance, the learner who shows a high degree of autonomy in one area can be nonautonomous in another.Little argues that it is difficult to define autonomy shortly and prefers 
discussing the widespread misconceptions about autonomy. The following issues are those Little has stated:

1. Autonomy is not a synonym for selfinstruction; in other words, autonomy is not limited to learning without a teacher.

2. In the classroom context, autonomy does not entail giving up responsibility on the part of teacher; it is not a matter of letting the learners get on with things as best they can.

3. Autonomy is not something that teachers do to learners; that is, it is not another teaching method.

4. Autonomy is not a single, easily described behavior.

5. Autonomy is not a steady state achieved by learners once.

So, what is autonomy? Holec sees autonomy as a capacity and critical ability to reflect on one's experience and to take charge of one's own learning. Little makes an addition to this definition by stating that autonomy enables learners to determine their objectives, define the content and process of their own learning, select their methods and techniques, and monitor and evaluate their progress and achievements. Both definitions emphasize the transfer of responsibility for learning from the teacher to the learner. With such responsibility the learner gains a greater degree of active involvement and better learning.

Holec argues that learner autonomy refers to encouraging students "to determine the objectives, to define the contents and progressions, to select methods and techniques to be used, to monitor the procedures of acquisition and to evaluate what has been acquired"

However, this about-face in paradigm, from teacher-dependent to teacher-independent is sometimes difficult for students who have been immersed in an educational system which has been predominately controlled by the teacher, who must now give up control and help these students become independent, self-sufficient, individuals. Autonomous learning, however, does not mean that the teacher's input and support is not needed. On the contrary, the teacher's role may change, becoming more of a facilitator than an expert, or "holder" of knowledge who transfers information to students, and it is precisely through classroom interaction that teachers can help them become conscious of and learn to make use of, this independence. Speaks of autonomy in terms of creating an atmosphere conducive to learning within the confines of the educational system where learners are given the possibility to be consciously involved in their own learning. Nunan mentions achieving "degrees of autonomy" which range from making students aware of the learning goals and materials, to making links between the content of classroom learning and the outside world.

Furthermore, Little suggested that learners who take responsibility for their learning are more likely to achieve their learning targets and hence likely to maintain their motivation. This acceptance of responsibility has both socio- 
affective and cognitive implications: it involves at once a positive attitude to learning and the development of a capacity to reflect on the content and process of learning under conscious control. Learners who are encouraged to take responsibility for their own work, by being given some control over what, how and when they learn, are more likely to be able to set realistic goals, plan programs of work, develop strategies for coping with new and unforeseen situations, and evaluate and assess their own work. They are able to learn how to learn from their own successes and failures.

furthers the role that autonomy plays in a teacher's life to stress that it not only shapes professional life, but social life too, stating that an autonomous teacher is self- directed, reflective and collaborative in the community as well as at the workplace in a "life plan. Autonomy, if exercised to its full effectiveness, needs to be an all-pervading philosophy of life shaping an individual's personal cognition and behavior in the community.

The concept of autonomy was also described by Nunan stated that the importance of learner autonomy understood as the capability_ not an inborn ability _to govern and regulate one's own thoughts, feelings, and actions freely and responsibly. It helps learners to find their individual learning styles, and start to believe in their own abilities and, finally, be autonomous learners. Generally "it highlights an important continuing role for teachers in promoting the psychological attributes and practical abilities involved in learner autonomy and in engaging students' existing autonomy within classroom practice. Kinds of writing, paying attention, preparing vocabularies as the preparation of the students learning are the including to their autonomous of their reading. Autonomy can be defined that to build up the students' independence in studying English and the teacher as facilitator. The autonomy refers to many things as the strategies, facilities of learning; teachers and students will be work together in bringing the effectiveness of the subject of the material.

\subsubsection{Concept of Reading Comprehension}

Based on Oxford Advanced Learner's Dictionary the word "comprehension" is defined as:

1) The ability to understand

2) An exercise that trains students to understands a language. Comprehension is a part of the communication process getting the thoughts that were in the author's mind into the reader's mind. Comprehension is the essence of reading because the goal of written language is communication of massage. In addition, comprehension also involves the recovery and interpretation of the abstract deep structural relations underlying sentences. Reading is the act of linking one idea to another. It is the activity to read, that has a purpose to get information from the reading material. If we want to learn language especially English, we have to study reading because reading is very important 
to get information when we learn English as a foreign language. Reading is a process of extracting meanings from the written language. It is a process of interpreting a message. It is an important skill in language teaching. It is a process of communication involving the researchers and the reader, the encoder and the decoder. It means that reading is an activity that aims primarily at understanding or constructing meaning from the written texts. Furthermore, Brown states that reading comprehension is primarily a matter or important skill to developing. It's very efficient used as strategy to understand a something that we read. It's means that the purpose of reading comprehension is to efficiency of reading. Furthermore, in reading activities, students should have good reading comprehension to get information from the reading text.

Janette states that, reading comprehension is a process that involves a reader to response of the text. Its complex process because comprehending or understanding a text is very important to us when we read a text. Comprehending a text involves many interaction between reader and what any our mind previous a read the text as well as variables related to the text itself. Based on the definition above, reading comprehension is looking for the information suggested from the text or written language, the readers understand the total meaning of the reading text is selections. The word "skill" in Oxford Advanced Learner's Dictionary skill is the ability to do something well. It means that skill is the ability to comprehend the passage requires the power of understanding the total meaning of the passage. A skill is something to do automatically without thinking about it and to do it the same way every time. Moreover, skill is an ability and capacity acquired through deliberate, systematic, and sustained effort to smoothly and adaptive carryout complex activities or job functions involving ideas, things, and people.

Based on the definition of above, the researchers concluded that reading comprehension skills can be defined as the reading process which the readers understand the passage of the text, understand total meaning of the text, both implicit and explicit meaning and to be able answer the question about the text well.

\section{a. Kinds of Reading Comprehension Skills}

Skilled readers, for instance:

1) Predicting what will happen next in a story.

2) Understanding the main idea and supporting detail of the text.

3) Understanding of the sequence, massage or structure of the text.

4) Understanding meaning of unknown words of the text.

5) Inferring the point of the reading material.

Reading comprehension is a skill, which the reader must be guess and answer question, and explain again what the purpose and massage 
author. After the reader reads the title of the text, the students predict what will happen next in a story to get the main ideas and supporting detail easily. So the students can understand the massage or the structure, understand the meaning of unknown words of the text of the text and inferring the point of the reading material. In this research the researchers focus on skills in understanding of massage or structure of the text and understanding main idea and the meaning of unknown words.

\section{b. The Factors that Influences Reading Comprehension}

Reading comprehension is a cognitive process that requires many skills and strategies. The readers are actively engaged with the text, they think about many things as they read to comprehend the text. There are several factors that affect the reading comprehension such as linguistic factors and non-linguistics factors. Linguistic factors include the knowledge about vocabularies and Meta cognitive knowledge of the second language structure, grammar and syntax. Meanwhile, non-linguistic factors include their prior knowledge and their experience. Lucy Hart has compiled a list, she make briefly explanation of factors that influence reading comprehension as follow:

1) Prior Knowledge

Prior knowledge plays an essential role in reading comprehension. Prior knowledge or usually called background knowledge is important to create new knowledge, without prior knowledge written material would be meaningless. Prior knowledge is expressed with words. The more knowledge must be activated to be useful, the more likely it is that the material will be understood. Prior knowledge helps the students to comprehend what are written and making inferences or predictions about the text. It means that prior knowledge is very important in reading to get meaning in passage.

2) Vocabulary

The students have mastered vocabulary skills affect their reading comprehension. Students must be able to comprehend a familiar words its relationship with other words within a text. Mastering vocabulary includes recognizing a word's part of speech, definition, useful context clues, and how it functions in a sentence. These vocabulary strategies can help improve comprehension.

3) Fluency

Reading with fluency allows students to retain information with accuracy, expression and increased speed. The ability to read fluently develops through reading practice. As students become fluent readers, they will spend less time trying to decipher the meaning of words or more time considering the overall meaning of the sentences. Over time, fluent readers will develop the ability to insightfully respond to a text. 
4) Active reading

Beginning readers often rely on skilled readers to guide them through a text. However, as readers develop, they will be able to monitor their own reading comprehension. Students can actively guide their own reading by targeting comprehension problems as they occur. Students can troubleshoot comprehension problems by recalling what they read, asking themselves questions or evaluating the text.

5) Critical thinking

The students can actively respond to a text more efficiently when they possess critical thinking skills. As students read, they can determine the main idea and supporting detail, the sequence of events and the overall structure of the text. Students will also be able to identify literary devices and their effect on the text. Having critical thinking skills help to deepen a students' comprehension of a text, resulting in a positive reading experience

\subsection{Theoretical Framework}

Constructivism which is popularly by Piaget is basically a theory based on observation and scientific study about how people learn. It says that people construct their own understanding and knowledge of the world, through experiencing things and reflecting on those experiences. When we encounter something new, we have to reconcile it with our previous ideas and experience, maybe changing what we believe, or maybe discarding the new information as irrelevant. In any case, we are active creators of our own knowledge. To do this, we must ask questions, explore, and assess what we know.

According to Bruner there are tree learning modus, they are enactive, iconic and symbolic. Enactive is doing, for example the students will give word cake, it will be understood directly to make a cake. The second step is iconic. After giving label image, the word of cake is studied by the picture and lastly is symbol. The students will read or listen to the word of cake and try to match with their experience in making cake.. The three steps will integrate each other to build up the students' activeness. The theoretical frame work can be shown below:

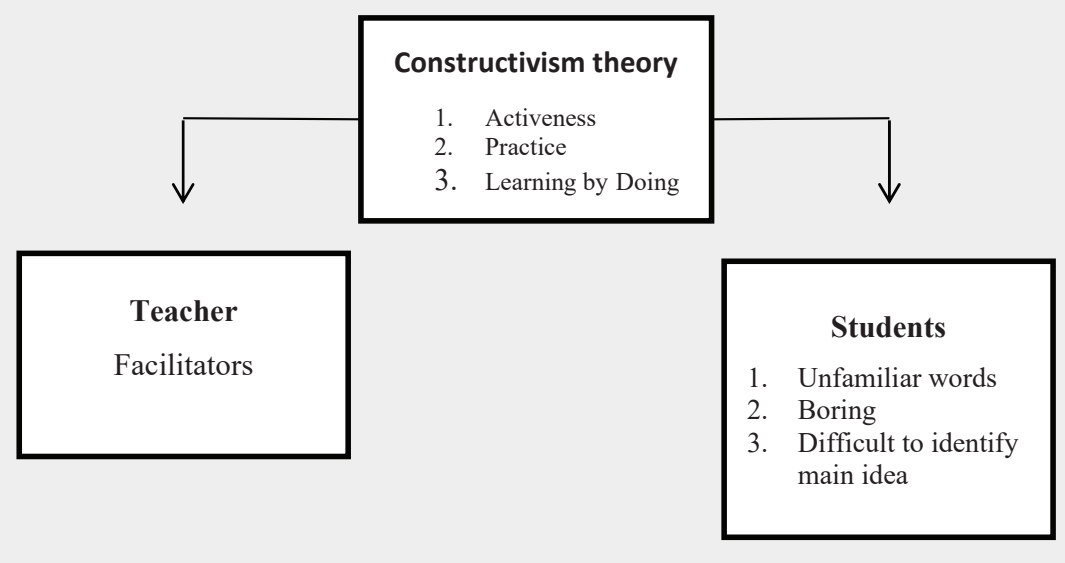




\subsection{Conceptual Framework}

Learning autonomy is meant to give opportunity to the students in independent in study English, which is teacher as facilitator and the students as learning-centered. The conceptual framework underlying this research is given in the following diagrams:

\section{Developing learner autonomy}

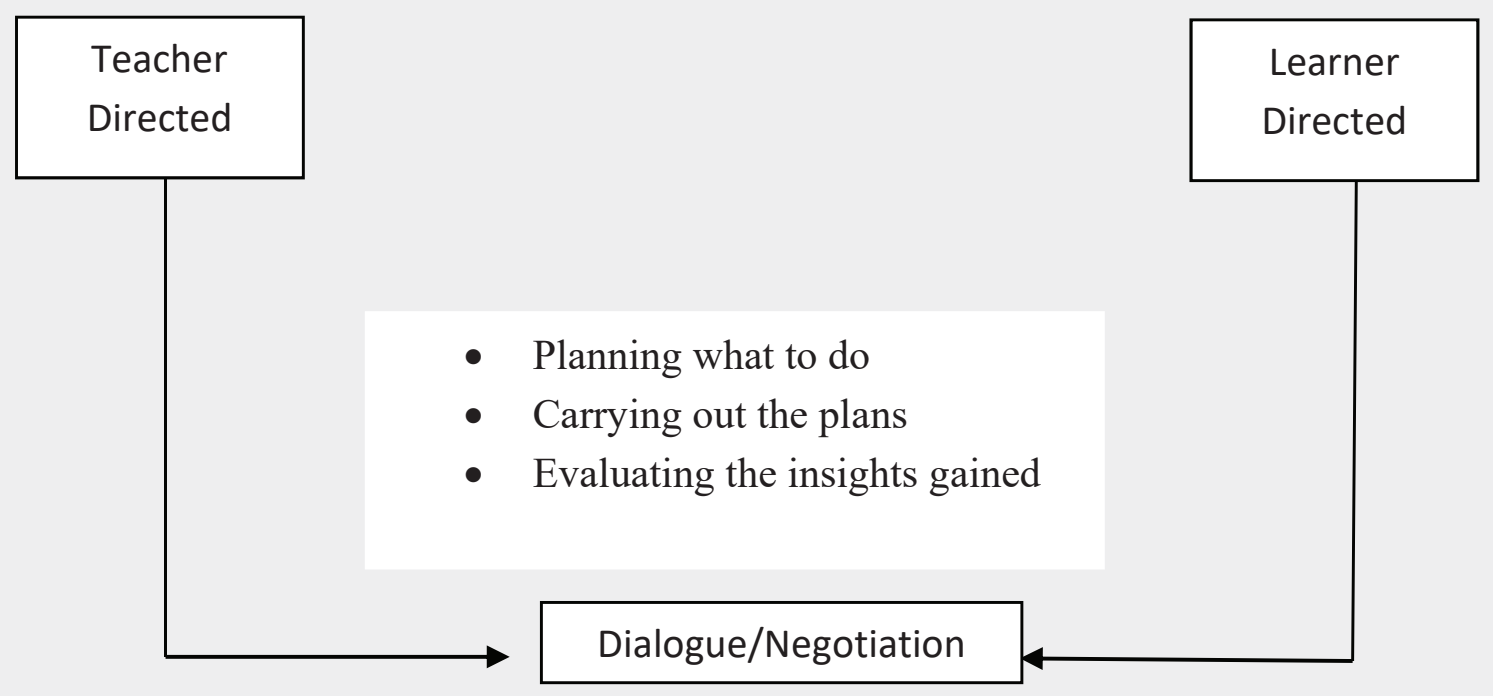

Autonomy has three aspects such as planing, doing the planing (monitoring) and evaluating. The students should be plan what will they study and then doing what they studied and the last is evaluating what they have studied before

\section{RESEARCH METHOD}

\subsection{Research Design}

This research used a mixed-method sequential explanatory design. This research consists of two phases: quantitative followed by qualitative. The research is focusing on the implementation of autonomy learning aspects especially for reading skill

\subsection{Research Variables}

This research consists of one variable namely independent variable. The independent variable is learning autonomy.

\subsection{Setting and Subject of the Research}

The population of this research is the eight year students of MTs DDI As-Salman Sidrap. There are three classes consist of VIII $a=23$, VIII $b=23$, and VIII $\mathrm{c}=26$ students and the total number are 70 students. The researchers used cluster random technique. The respondents of the research are taken from one class 
that is class VIIIA which has 23 students because the English teacher suggested doing research that class.

\subsection{Instrument of the Research}

To answer the first and the second research questions, this research used questioner, while to answer the third research question, this research applied interview.

\section{DISCUSSION}

The students had already implemented the autonomous learning in their reading class. The result of observation sheets showed that the students were active from the starting of the reading class until the end of the class. The data were analyzed though grounded theory, Setiyadi argues that the analysis commonly construct the theory based on the data from the research (grounded theory). In students' preparation sources (dictionary) and the students' involvement in the questioning the topic, only half of the students were doing it. Some students were active in questioning the material. The result of the observations indicated that the aspects of autonomous learning had already implemented by the students. In the class, the researchers observed that the students dominated the class and the teacher supported them with clues to attract their opinion about the text and materials. ${ }^{1}$

Benson says autonomy can be described as a capacity to take charge of, or take responsibility for, or control over your own learning. During the reading class the teacher made the students working first

${ }^{1}$ Setiadi, Bambang. 2006. Metode Penelitian untuk Pengajaran bahasa Asing.Yogyakarta: Graha Ilmu in a group or pair before they have individual task. The teacher also gave them time to have discussion, looked the dictionaries, and asked questions. This condition showed the autonomous learning and was supported by Little's theories that says teacher should help their students set their learning goals creating a friendly atmosphere in the classroom 9 which leads to discussion, analysis and evaluation; encouraging them to work collaboratively in small groups; asking the learners to keep a record of their learning and evaluate their progress both as individual learners and as a class again in the target language are among the tasks.

There are three aspects of learning autonomy such as self-planing which is $56.83 \%$ whose answer is yes, self-monitoring $81.85 \%$ and self-evaluating which is $62.53 \%$, who's the students answer is yes. So, the students still weak in self-planing. The criteria ca be seen below:

The criteria of implementation of autonomous aspects in learning process:

$\begin{array}{lll}\text { No } & \text { Criteria } & \text { Percentage }(\%) \\ \text { 1. } & \text { Poor } & 40 \%-59 \% \\ \text { 2. } & \text { Enough } & 60 \%-69 \% \\ \text { 3. } & \text { Good } & 70 \%-79 \% \\ \text { 4. } & \text { Very Good } & 80 \%-100 \%\end{array}$

Based on the explanation above, it can be inferred that the students have already implemented the aspects of autonomous learning in their class. From the questionnaires the students' self-planning showed 56.83 points. It meant that the implementation of self-planning in the poor criteria. The weakness was in students' material preparation. Only four students claimed that they learn the material before 
the class begins. Students admitted that they rarely learn the material before the class begins and they prefer to comprehend the material when the teacher started to deliver it. 10 The questionnaires result showed that the students got $81.85 \%$ for the selfmonitoring. This meant that the students' selfmonitoring was good. The weakness of students' self-monitoring was in questioning the material. The result of the questionnaire showed that there are only half of all students (11 students) who active in questioning the material. The students seemed very active in responding the material but have weakness in questioning what the material told about. So the teacher almost always asked their opinion because they were active in responding the material but not really active when it related to questioning the material.

For the self-evaluating half of the class implemented it. Students' self-evaluating showed $62.53 \%$, this meant that students have enough criteria in self- evaluating. The observation sheets showed that in the students' self-evaluating around 16-17 students involved actively. This means more than half of the class implemented self-evaluating from 22 students in the class. For the students' selfevaluating result from the questionnaires, the students seemed to be weak in re-discussing the material with the others and re-study the material after the class is over. Only six students claimed that they are active in re-discussing the material after the class over and nine students claimed that they re-study the material after the class over. But the students were actively in asking the difficulty to the teacher and finding some difficulty by themselves. Holec (1981) argues that learner autonomy refers to encouraging students "to determine the objectives, to define the contents and progressions, to select methods and techniques to be used, to monitor the procedures of acquisition and to evaluate what has been acquired".

Based on the interview to the English teacher, it was found that the students got difficulties in the selfevaluating. The teacher said that the students were rarely having questions before the class over. When the teacher asked them about their understanding of the material, the students only said they have understood. This condition made the teacher not really sure about the students' material mastering. The teacher said that from the result of the test she can be sure about the students understanding. Contrary to the result of questionnaires, the students showed some weaknesses in self-planning.

They admitted that they lacked in material preparation before the class begin. It seemed that the students did not study about the material at their house. And the students also have difficulties in preparing the source of the reading class like a dictionary for each person. There were only half of the students brought dictionary and the rest borrowed from others. It seemed the difficulties happened because the students lack of intrinsic motivation, because their intrinsic motivation is closely related to the perception of being somehow in control of their own learning and learning preparation. Based on the questionnaires, it showed that almost of the students did not study the next material in their house and they seemed study only during the class. The students also have weakness in re-study the material and re-discuss the material that has learned with their friends. For the reading strategies 
almost all of students have it, they active in working individually and group, active in correcting the task, active in asking the difficulty about the material and also active in finding the difficulties by themselves.

\section{BIBLIOGRAPHY}

Ahmad Anwar, 2014. University EFL Learners' Perceptions of Their Autonomous Learning Responsibilities and Abilities. Birzeit University: Palestina.

Akhtar Nurbegum, Rayhana Fatema Chowdhusry, 2016. The Factors That Affect Learner Autonomy In Learning English As A Foreign Language (Efl) At Tertiary Level In Bangladesh.

Ahmadzadeh, 2014, Learner Autonomy In Practice.

Ayfer Koçak, 2003, a Study on Learners' Readiness for Autonomous Learning Of English as a foreign language, PDF. Downloaded on 28 March 2018

Balcikanli Cem, 2010. learner Autonomy in Language Learning Student Teacher's Beliefs.

Barfield, A. \& Brown, S.H, 2001. Reconstructing Autonomy in Language Education. (Basingtoke: Palgrave Macmillan)

Benson, P. (2001). Teaching and researching autonomy in language learning. London: Longman.

Benson, P. 2006. Autonomy in Language Teaching and Learning. In Language Teaching and Learning. Cambridge University Press.

Begum, The Factors That Affect Learner Autonomy In Learning English As A Foreign Language (Efl) At Tertiary Level In Bangladesh. (Asia Pasific Jurnal of Bangladesh:2016).

Breen, M.P.,\& Mann, S.J. 1997. Autonomy \& Independence in Language Learning. Harlow: Addison Wesley Longman Ltd, 132-149.
Chan, V. 2001. Readiness for learner autonomy: What do our learners tell us? Teaching in Higher Education, 6(4). 505-519.

Cubukcu, Feryal. 2009. Acquisition, Development and Assessment of Learner Autonomy. Dokuz : Eylul University.

Cecep Kustandi and Bambang Sutjipto,(2011) Media Pembelajaran, Bogor: GhaliaIndonesia,

Dam L, 1996. Learner Autonomy 3. From Theory to Classroom Practice. Dublin Authentic.

Djamiah Husain, 2011, Fostering Autonomous Learning Inside and Outside the Classroom in Language Learning, Badan Penerbit UNM.

Fitri wulansari, hery yufrizal, hartati hasan, 2014. Analyzing Autonomous Learning at First Grade Of Junior High School Students, (PDF)

Fotiadou,2016,Learner Autonomy As A Factor Of The Learning Process In Distance Educati on.

Holec. H. 1981. Autonomy in Foreign Language Learning. Oxford:Pergamon. J. R. Fraenkel \& N. E. Wallen. 2007. How to design and Evaluate Research in Education. Singapore: McGraw Hill.

Little, D. 1991. Learner Autonomy. 1: Definitions, Issues and Problems. Dublin: Authentik.

Little, D. (2008). Learner Autonomy and Second/ Foreign Language Learning. Subject Centre for Languages.

Louis, Helping Students Become Autonomous Learners: Can Technology Help?.

Mc Arthur, 1998. The English Languages. Cambridge University Press.

Nunan, D. 1999. Second Language Learning and Teaching. Boston, MA: Heinle \&Heinle.

Orakci, 2017 Learner Autonomy Scale : A Scale Development Study. 
Rubena, 2003. Helping students become autonomous learners: can technology help?

Setiadi, Bambang. 2006. Metode Penelitian untuk Pengajaran bahasa Asing.Yogyakarta: Graha Ilmu.
Soleh Agus, 2015. Promoting Autonomous Learning In Reading Class. Malang: Kanjuruhan Universitry.

Zhong, A Study Of Autonomy English Learning On The Internet, 2018. 